\section{Sciensage}

Journal of Advanced Scientific Research

Available online through https: / /sciensage.info
ISSN: 0976-9595

Research Article

DOI: $10.55218 /$ JASR. 202213144

\title{
PENICILLIN PRODUCTION WITH FREE \& IMMOBILIZED PENICILLIUM CHRYSOGENUM CELLS \& DETERMINATION OF OXYGEN TRANSFER RATE IN STIRRED TANK REACTOR
}

\author{
A. Swaroopa Rani*1, A. Kiran Kumar ${ }^{2}$ \\ ${ }^{1}$ Department of Bio-Technology, Oil Technology \& Pharmaceutical Research Institute, JNTUA, Ananthapuramu, \\ Andhra Pradesh, India \\ ${ }^{2}$ Department of Chemistry, University College of Technology, Osmania University-Telangana State, India \\ *Corresponding author: daddala.gunabhushana@gmail.com
}

\begin{abstract}
Penicillin production by free and agar immobilized Penicillium chrysogenum cells was investigated in a stirred tank reactor. Penicillin production was increased two times with immobilized cells. In order to verify the oxygen transfer efficiency in STR, oxygen mass transfer coefficient was determined by using dynamic gassing out method at the end of steady state operation of the reactor after achieving penicillin production. The oxygen mass transfer coefficient $\left(\mathrm{K}_{\mathrm{L}} \mathrm{a}\right)$ obtained in STR with 20\% (V/V) agar immobilized beads, at 1 VVM (Unit volume of air per unit volume of the reactor per minute) of air flow rate and 250 RPM of agitator speed gave maximum amount of antibiotic production in the reactor. The oxygen mass transfer coefficient $\left(\mathrm{K}_{\mathrm{L}} \mathrm{a}\right)$ obtained in stirred tank reactor (STR) is $18 \mathrm{hr}^{-1}$.
\end{abstract}

Keywords: Immobilization, Penicillin, Penicillium chrysogenum, Stirred tank reactor, Dynamic gassing out method, Volumetric oxygen mass transfer coefficient $\left(\mathrm{K}_{\mathrm{L}} \mathrm{a}\right)$.

\section{INTRODUCTION}

Antibiotic production is a key area in applied microbiology and antibiotics are usually produced by batch/fed batch fermentation using free cell cultures. To enhance the productivity and to improve the economics, much attention has been paid on the improvement of the cultures employed in the antibiotic production. It is worthwhile to closely examine the fermentation strategies adopted to improve the productivity of the system and whole cell immobilization technology appears to be attractive for antibiotic fermentation. Immobilized microbial cells offer several advantages over free living cells in metabolic production. They can work as effective biocatalysts due to their characteristics of self generating and proliferation complex catalysts system. Several attempts have been made to immobilize various microbial species on different support matrices for antibiotic production. Among different methods employed, calcium alginate entrapment has shown considerable promise in antibiotic production. Reports are available on production of bacitracin [1], nikkomycin [2], neomycin [3], patulin [4, 5], erythromycin [6], actinomycine [7], candicidine [8] and cephalosporine [9] using immobilized cells [10].
Most of the available reports on antibiotic production using immobilized cells are limited to shake flask culture and only a few reports are available on bioreactor studies [11]. Earlier reports on immobilization of penicillin G-acylase in chitosan beads were studied by Braun, J [12] and Guisan [13]. But as of now, reports are only based on agar as gelling agent [14] and use of agar beads for penicillin production is not yet reported. The main objectives of the present investigation is to study about (a) whole cell immobilization by entrapment in agar for penicillin production using Penicillium chrysogenum in Stirred tanks reactor and comparison of the same with free cells under similar conditions, (b) Inadequate supply of oxygen is one of the major problem in industrial production of antibiotics. Efficient oxygen transfer is crucial especially for systems contaminating high biomass loading [15]. In antibiotic production, oxygen demand is the key parameter hence oxygen supply plays a vital role in fermentation systems. It is difficult to meet oxygen demand especially in viscous fermentation broth. Special fermentor designs are required to enhance the rate of oxygen transfer in fermentation systems involving high oxygen demand. The design of a fermentor for optimum oxygen transfer requires a thorough 
understanding of the transfer and utilization of oxygen in microbial systems [16]. The DO concentration of the fermentation broth has a profound effect on the performance of aerobic fermentation systems. The problem solving approach usually involves improvements in design of the bioreactor, agitator and sparger as well as the use of oxygen-enriched air [17].

Penicillium chrysogenum is sensitive to dissolved oxygen changes, and in the absence of dissolved oxygen, the cells starve. According to the earlier authors, the cells are much more sensitive to oxygen starvation during the growth phase than during the production phase [18]. This indicates that the lack of the oxygen mainly influences the basic metabolism rather than biosynthesis of antibiotics. During the growth and production phases, dissolved oxygen is necessary. Dissolved oxygen depends on the specific interfacial area of the bubbles in submerged cultures, which is a function of the property of the medium (viscosity, coalescence promoting/ repressing properties). Oxygen mass transfer is a function of process and cost. Hence estimation of oxygen mass transfer coefficient in stirred tank reactor for the production of antibiotics is essential for the design and development of a bioreactor for efficient and economical production of antibiotics [19].

The present study is aimed at determination of volumetric oxygen mass transfer co-efficient $\left(\mathrm{K}_{\mathrm{L}} \mathrm{a}\right)$ using dynamic gassing out method in a stirred tank bioreactor with immobilized cells of Penicillium chrysogenum for the production of penicillin. This paper indicates the enhanced levels of penicillin production using immobilized agar beads, which is economically feasible and discusses the ways for improving reactor performances.

\section{MATERIAL AND METHODS}

\subsection{Microorganism and Culture Conditions}

In the present study, the strain Penicillium chrysogenum (ATCC 10238) was used and maintained on agar slopes, medium containing $\left(\mathrm{gl}^{-1}\right)$ of; malt extract, 20; peptone, 1.0; Agar, 20 and distilled water $1 \mathrm{~L}$,at $\mathrm{pH} 6.5 \pm 0.2$, temperature $25^{\circ} \mathrm{C}$ and subcultured at monthly intervals. Five $\mathrm{ml}$ of sterile distilled water was added to a well sporulated slant (7-day old) and spores removed by scrapping. The spore suspension prepared was then added to a $250 \mathrm{ml}$ Erlenmeyer flask containing $45 \mathrm{ml}$ of growth medium incubated on a rotary shaker at $180 \mathrm{rpm}$ at $25^{\circ} \mathrm{C}$. After $72 \mathrm{hrs}$ of incubation, the culture broth was centrifuged; the cell pellet washed with sterile $0.5 \% \mathrm{NaCl}$ solution. This cell suspension was used as inoculum for further experiments and also for the immobilization of whole cells.

\subsubsection{Immobilization of Whole Cells}

Cells were immobilized using agar by entrapment method [20]. 2\% agar was mixed with $0.2 \%$ cells on dry weight basis (DCW) (W/V) and mixed well to get uniform suspension, the solution was then dropped into paraffin oil in the bead form with the help of peristaltic pump (Watson and Marlow. U.K) through small orifice. The beads then formed were cured for $2 \mathrm{hrs}$ by incubating in oil and washed twice with sterile saline $(1 \% \mathrm{NaCl} \mathrm{W} / \mathrm{V}$ solution) and stored in saline solution at $4{ }^{\circ} \mathrm{C}$ for further use. All these steps were carried out under aseptic conditions.

\subsection{Fermentation in Stirred Tank Reactor}

Experiments were conducted in batch STR (B.Braun Biostat, Germany) for the production of penicillin using agar immobilized cells of Penicillium chrysogenum. The composition of production media consisted of $\left(\mathrm{gl}^{-1}\right)$ : Lactose monohydrate, $10 ; \mathrm{KH}_{2} \mathrm{PO}_{4}, 3.4 ; \mathrm{NH}_{4} \mathrm{Cl}, 1.21$; Phenyl acetic acid,0.3; $\mathrm{K}_{2} \mathrm{SO}_{4}, 3.95 ; \mathrm{MgSO}_{4} .7 \mathrm{H}_{2} \mathrm{O}$, 0.25; ammonia,30. Lactose was autoclaved separately. The salts were adjusted to $\mathrm{pH} 6.0$ with $\mathrm{NaOH} / \mathrm{HCl}$ prior to sterilization. The reactor and accessories were sterilized separately. The working volume of the reactor was 1 liter and filled with $20 \%(\mathrm{~V} / \mathrm{V})$ of immobilized beads and the average size of the beads was $2.0 \mathrm{~mm}$. Continuous sterile air was supplied through air filters (Watman $50 \mu$ ) at the rate of $1 \mathrm{VVM}$ (unit volume of air per unit volume of the reactor per minute) and impeller was provided for mixing with a speed of 250RPM.

\subsection{Analytical Methods}

Samples were drawn in eppendr of tubes everyday under sterile conditions of antibiotic assay, carbohydrate estimation and $\mathrm{pH}$. Penicillin concentration was determined by plate diffusion method using E.coli as test organism along with standard penicillin disc $(10 \mathrm{mg}, \mathrm{Hi}-$ media) in every plate [21]. Carbohydrate was estimated by Anthrone method [22]. The volumetric mass transfer coefficient $\left(\mathrm{K}_{\mathrm{L}} \mathrm{a}\right)$ was determined using the dynamic method by DO meter [23].

\subsection{Determination of $\mathrm{K}_{\mathrm{L}}$ a by Dynamic Method of Gassing Out}

Aeration and agitation are important variables to provide effective oxygen transfer rate during aerobic bioprocesses. Hence, the knowledge of the volumetric 
mass transfer coefficient $\left(k_{L} a\right)$ is required. The determination of $\mathrm{k}_{\mathrm{L}} \mathrm{a}$ in a bioreactor is essential in order to establish its aeration efficiency and to quantify the effects of operating variables on oxygen supply.

Oxygen transfer in aerobic bioprocesses is essential and any shortage of oxygen vastly affects the process performance. Therefore, oxygen mass transfer is one of the most important phenomena in the design and operation of mixing-sparging equipment for bioreactors. It can be described and analyzed by means of the volumetric mass transfer coefficient, $\mathrm{k}_{\mathrm{L}} \mathrm{a}$. The values of $\mathrm{k}_{\mathrm{L}} \mathrm{a}$ are affected by many factors, such as geometrical and operating characteristics of the reactor (type of impeller, the geometry of the bioreactor, the agitation speed and the air flow rate), media composition and properties, concentration and microorganism's morphology and biocatalyst's properties as shown in Fig. 1.

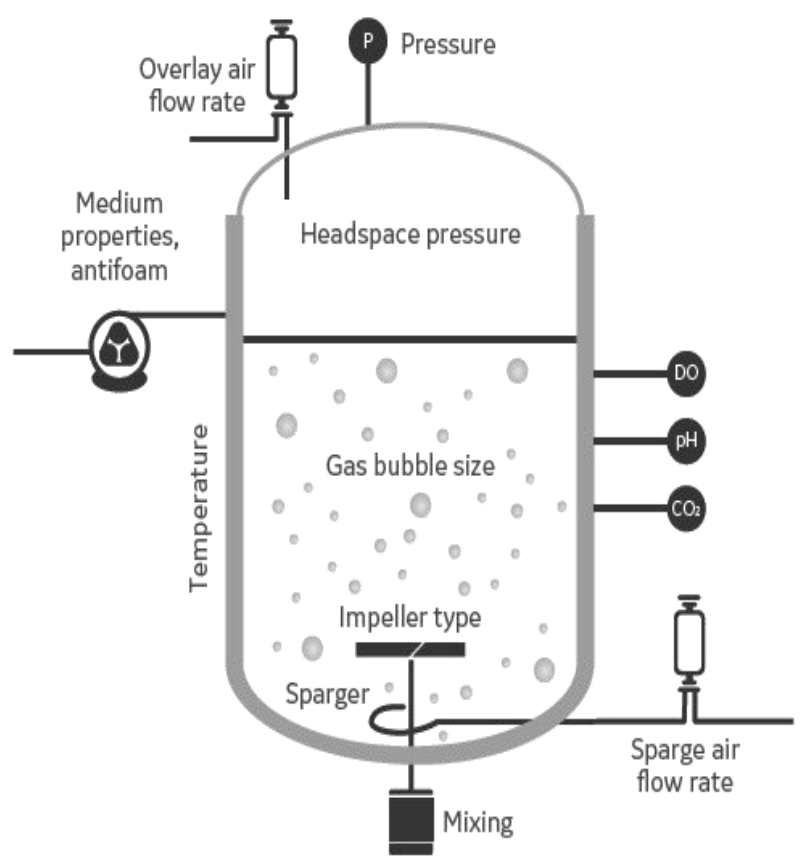

Fig. 1: Key Factors that Influence $K_{L}$ a values in a Bioreactor Process

This method is the simplest one since it requires only a dissolved oxygen probe [23]. It is mainly based upon the dynamic oxygen balance in a batch culture, which has the following form:

$\mathrm{dC}_{\mathrm{L}} / \mathrm{dt}=\mathrm{K}_{\mathrm{L}} \mathrm{a}\left(\mathrm{C} *_{-} \mathrm{C}_{\mathrm{L}}\right)-\mathrm{QO}_{2} \mathrm{X}$

Where $\mathrm{QO}_{2}$ is the rate of oxygen consumption per unit mass of cells (mm $\left.\mathrm{O}_{2} \mathrm{~g}^{-1} \mathrm{~h}^{-1}\right)$, rearranging equation (1) gives;
$\mathrm{C}_{\mathrm{L}}=\mathrm{C}^{*}-\left(\mathrm{QO}_{2} \underline{\mathrm{X}}+\mathrm{dC}_{\underline{L}} / \mathrm{dt}\right)$

$\mathrm{K}_{\mathrm{L}} \mathrm{a}$

The air supply is turned off at a certain time during fermentation and the variation of $\mathrm{C}_{\mathrm{L}}$ with time is followed with the aid of a DO probe. Since, the term $\mathrm{K}_{\mathrm{L}} \mathrm{a}\left(\mathrm{C}^{*}-\mathrm{C}_{\mathrm{L}}\right)$ becomes zero when air is turned off, the $\mathrm{C}_{\mathrm{L}}$ value decreases linearly with time according to equation (1). The slope of the $\mathrm{C}_{\mathrm{L}} \mathrm{Vs}$ time curve is a value of $\mathrm{QO}_{2}$ $\mathrm{X}$.The air was then turned on and the increase in DO with time was followed. Having determined the $\mathrm{QO}_{2} \mathrm{X}$ value, $\mathrm{C}_{\mathrm{L}}$ was plotted against $\left(\mathrm{QO}_{2} \mathrm{X}+\mathrm{d} \mathrm{C}_{\mathrm{L}} / \mathrm{dt}\right)$. The slope of this plot is equal to the reciprocal of $\mathrm{K}_{\mathrm{L}} \mathrm{a}$.

\section{RESULTS AND DISCUSSION}

\subsection{Stirred Tank Reactor Studies of Penicillin Production Using Penicillium Chrysogenum}

Penicillin production using Penicillium chrysogenum under free and agar immobilized states was investigated in the stirred tank reactor. Immobilized cells have produced two-times more antibiotic than the free cells as shown in Fig. 2.

The maximum amount of Penicillin production (425. 86 $\mu \mathrm{gml}^{-1}$ ) was produced at the end of $48 \mathrm{hrs}$ by immobilized cells, whereas, the peak antibiotic production activity was observed after $72 \mathrm{hrs}$ in the free cell fermentation. The volumetric productivity of the immobilized cell fermentation is $6.0 \mathrm{mgl}^{-1} \mathrm{~h}^{-1}$, which is $60 \%$ higher than the free cell fermentation $\left(2.5 \mathrm{mgl}^{-1}\right.$ $\left.\mathrm{h}^{-1}\right)$. Free cells showed a lag phase of $24 \mathrm{hrs}$, whereas immobilized cells commenced the production of antibiotic immediately. This is due to the induced stress imposed by the immobilization process, which is not present in free cell fermentations.

The optimized production medium resulted in good yield of penicillin production. The carbon and nitrogen (lactose and ammonia) concentrations were selected by conducting various experiments by varying carbon and nitrogen sources in the above production media. It was seen that enhanced supplementation of carbon and nitrogen sources are neither economic nor effective for penicillin production with immobilized cells of Penicillium chrysogenum. The observations suggest that antibiotic and biomass can be effectively decoupled by appropriately selecting the key nutrient concentration during fermentation. $(10 \mathrm{~g} / \mathrm{l})$ of the lactose in the media at zero hrs of fermentation indicates that under limited carbon sources supplementation, Penicillium chrysogenum cells can divert these sources to secondary metabolite production rather than cell mass production under 
immobilized conditions. Similarly observations were also noticed for patulin production with P.urticae by
Berk et.al [4, 24] and antibiotic production with Penicillium chrysogenum by Kim et.al [25].

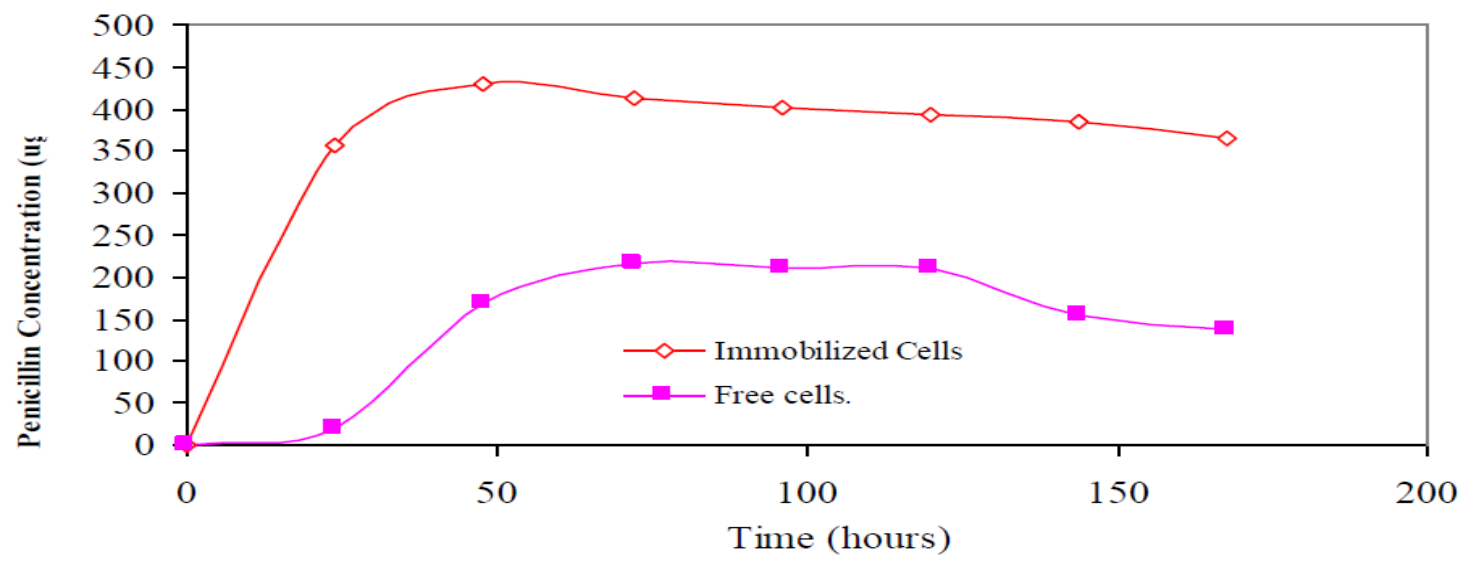

Fig. 2: Improved Penicillin production by agar immobilized cells over free cells

\subsection{Determination of $K_{L}$ a Values for $S T R$}

Substrate and immobilized cells were transferred to STR. Air was bubbled continuously to the reactor and antibiotic concentration was monitored regularly and it was observed that, antibiotic activity started declining after $10^{\text {th }}$ day onwards. Hence, the experiment was terminated at $10^{\text {th }}$ day. On the same day, experiment was carried out for the determination of $\mathrm{K}_{\mathrm{L}}$ a by dynamic method. In STR the dissolved oxygen was measured for every 30 seconds up 150 seconds. The dissolved oxygen (DO) concentration was stable at $6.0 \mathrm{mg} \cdot \mathrm{l}^{-1}$. Air supply was stopped at this condition (150 sec's) and decrease in DO was recorded until 600 sec's. The DO concentration decreased from $6.0 \mathrm{mg} . \mathrm{l}^{-1}$ to $5.6 \mathrm{mg} . \mathrm{l}^{-1}$ during this period. Again air supply was started to the reactor at this juncture (600 sec's) and DO was recorded. It was observed that DO recovered to 6.0 mg. $\mathrm{l}^{-1}$ at 950 sec's and remained stable further. The results were plotted and shown in a Fig.3.

Specific rate of oxygen consumption over a volume of liquid $\left(\mathrm{QO}_{2} \mathrm{X}\right)$ was determined by measuring slope of the curve during the absence of air supply from this graph. The rate of increase in $\mathrm{DO}\left(\mathrm{dC}_{\mathrm{L}} / \mathrm{dt}\right)$ was determined at four points when the air supply was resumed on 600 sec's. Another plot was drawn as shown in Fig.4, between $\left(\mathrm{dC}_{\mathrm{L}} / \mathrm{dt}+\mathrm{QO}_{2} \mathrm{X}\right) \mathrm{Vs}$ DO concentration. The slope of this graph was the reciprocal of the volumetric mass transfer coefficient. The $K_{L}$ a value for the STR was found to be $18 \mathrm{hr}^{-1}$. It is obvious that the values of $\mathrm{k}_{\mathrm{L}}$ a are not so sensible to the variation of the input air flow rate in comparison with variation of the agitation speed, especially in large reactors.

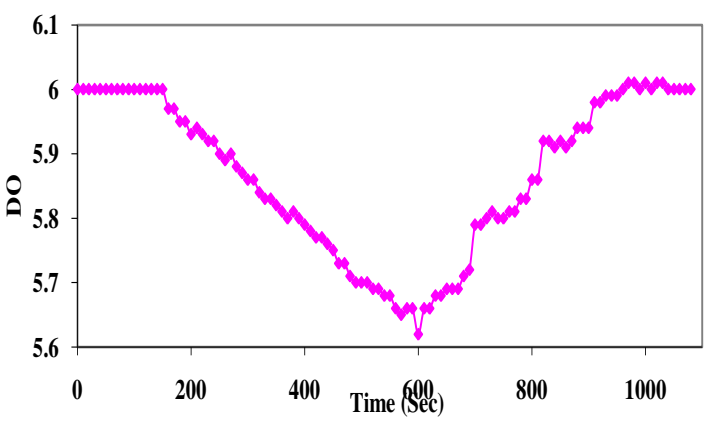

Fig. 3: Determination of $K_{L}$ a in STR

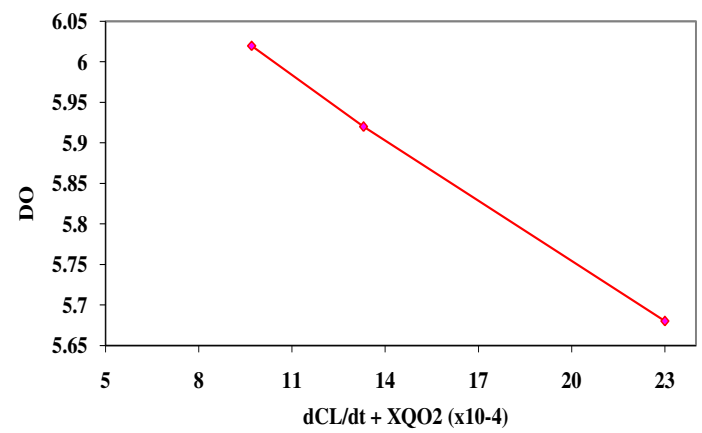

Fig. 4: Dynamic Method for the Determination of $K_{L}$ a Values

Oxygen transfer Co efficient $\left(\mathrm{K}_{\mathrm{L}} \mathrm{a}\right)$ studies reflect that confined cell fermentation maintains a much more favorable system, as the gas-liquid mass transfer properties of the culture become enhanced, possibly because of restructuring of the filamentous morphology of the cells. 
The performance of the reactor in terms of oxygen mass transfer at a $\mathrm{K}_{\mathrm{L}}$ a value of $18 \mathrm{hr}^{-1}$, has the advantages of the immobilized process demands a rigorous study of the limitation to mass transfer of the reagents, especially oxygen, [26, 27] therefore, use of immobilized cells will increase the oxygen mass transfer rate $[28,29]$.

\section{CONCLUSION}

Current process for the production of penicillin is primarily dependent upon the use of very slow growing free cells and is not designed for the repeated use of the cells. However, this study clearly indicates that immobilized cells have potential to extend the production of penicillin yield for more number of days in STR and is more suitable for repeated use of fermentation cycles since; the entrapment of cells in agar beads provides mechanical protection to the cells by the matrix. Agar immobilized cells have shown two fold enhanced penicillin production compared to free cells in STR.

The most suitable method for $\mathrm{k}_{\mathrm{L}}$ a measurement requires to take into account the range of the variables as power input, volume and type of the reactor, characteristics of gas and liquid phase. The dynamic method is the most widely used, with a small degree of approximations for gas-liquid mixing in the reactor. This method is suitable for large scale bioreactors with errors less than $10 \%$, over the entire range of the operating conditions encountered in the industrial ferment or operations.

The high volumetric oxygen mass transfer coefficient performance in stirred tank reactor represented excellent performance in terms of good aeration and antibiotic production. Use of agar immobilized cells of Penicillium chrysogenum in stirred tank reactor is more economical for the production of Penicillin.

\section{Nomenclature}

$\mathrm{K}_{\mathrm{L}} \mathrm{a}=$ Volumetric oxygen transfer Coefficient, $\mathrm{hr}^{-1}$.

$\mathrm{C}_{\mathrm{L}}=$ Saturated dissolved oxygen concentration liquid, $\mathrm{mg} \cdot \mathrm{l}^{-1}$.

$\mathrm{C}^{*}=$ Equilibrium dissolved oxygen concentration in liquid, mg. $1^{-1}$.

$\mathrm{X}=$ Biomass concentration in liquid, $\mathrm{mg} \cdot \mathrm{l}^{-1}$.

$\mathrm{QO}_{2}=$ Specific rate of oxygen Consumption $\mathrm{mMO}_{2} \mathrm{~g}^{-1}$ $\mathrm{hr}^{-1}$.

$\mathrm{dc}_{\mathrm{L}} / \mathrm{dt}=$ Change in DO concentration in liquid with time $\mathrm{m} . \mathrm{gl}^{-1} \mathrm{hr}^{-1}$.

DO $=$ Dissolved Oxygen

STR $=$ Stirred tank reactor

\section{Conflict of interest}

None declared

\section{REFERENCES}

1. Morikawa Y, Karube I, Suzukis S. Biotechnology Bioengineering, 1980; 22:1015-1023.

2. Veelken M, Pape H. European Journal of Applied Microbiology and Biotechnology, 1982; 15:206-210.

3. Park SO, Ohta N, Okabe M. Journal of Fermentation Bioengineering, 1994; 78:265-268.

4. Brek D, Behie LA, Jones A, Lesser B, Gaucher M. Candian Journal of Chemical Engineering, 1984; 62:112-119.

5. Deo YM, Costerton JW. Gaucher RM. Applied Microbiology and Biotechnology, 1985; 21:220-225.

6. Bandyopadhyay A, Das AK, Mandal SK. Biotechnology Letters, 1993; 15:1003-1006.

7. Dalili M, Chau PC. Biotechnology Letters, 1988; 10:331-336.

8. Constsantinides A, Mehta N. Biotechnology Bioengineering, 1991; 37:1010-1020.

9. Prasad K, Sridhar K, Sridhar P. Process Biochemistry, 1999; 34:325-328.

10. Ramakrishna SV, Prakasham RS. Current Science, 1999; 77:87-100.

11. Park Y, Davis ME, Wallis DA. Biotechnol.Bioengg, 1984; 26:457.

12. BraunJ, Le Chun P, Le GolficF. Biotechnol.Bioengg, 1989; 33(2):242-246.

13. Guisan. Jose Manvel. Alvaro, Gregoro. Geinos, Marie delcarman-span. E.S, 1987; 2(5):853-870.

14. Scholton HJ, Pierik RLM. Sci. Hortic (Amsterdam). 1998; 77(1, 2):109-116.

15. Bailey JE, Ollis DF, Biochemical Engineering Fundamentals. 2nd ed. Mc Graw- Hill, New York: 635; 1986.

16. Duran PM. Bioprocess Engineering principles, $X^{\text {th }}$ ed. Academic Press 198; 2003.

17. Moo Young M, Blanch HW. Design of biochemical reactors, Adv. Biochem. Eng., 1981; 19:1.

18. Larsson G, EnforsSO. App. Micro. Biotech.1985; $21: 228$

19. Murat Elibola, Ferda Marvituna. Biochem. Eng J, 1999; 3:1.

20. WittlerR, Schugerl K. Appl. Microbiol. Biotechnol, 1985; 21:348-355.

21. Bauer AW, Kirby WM. American J. Clin. Pathol, 1996; 45:491.

22. Loewus FA. Anal. Chem, 1952; 24:219. 
23. Kargi and Murray Moo Young.Comprehensive biotechnology, Vol 2.Design and operation of bioreactors, 21. Pergamon Press: Canada 21; 1985.

24. Berk D, Behie LA, Jones A, Lesser BH, Gaucher M.Canadian Journal of Chemical Engineering, 1984; 62:120-124.

25. Kim JH, Oh Dk, Park SK, Wallis DA. Biotechnology Bioengg, 1986; 28:1838-1844.
26. Xuemei Li, Xiao Dong Chena, Naixing Chen.Bio chem. Eng J, 2004; 17:65.

27. Araujo MLGC, Giordano RC, Hokka CO. Biotech. Bioeng, 1999; 63:593.

28. Swaroopa Rani A, Annapurna Jetty, Ramakrishna SV. Chem. Biochem. Eng Q, 2003; 17:119.

29. Swaroopa Rani A, Annapurna Jetty, Ramakrishna SV. Ind. J. Biotech, 2004; 3:394. 